\title{
Study of the efficiency of on-board electricity generation in the city bus
}

This paper discusses the methodologies to investigate the efficiency of on-board electricity generation in the city bus. The research object, i.e. the Mercedes Conecto was tested under steady conditions. A chassis dynamometer, i.e. the MAHA LPS 3000 LKW provided the same conditions during the entire research. The paper presents the samples of the measurements performed at a single operating point of a given crankshaft speed and torque. This operating point was specified in line with the guidelines for the WHSC test. In our study, an electrical load was changed with an extra receiver, or a light bulb, at a fixed amount of fuel. The electrical loads were $0.4 \mathrm{~kW}$, $1.6 \mathrm{~kW}$ and $2.8 \mathrm{~kW}$. The research results enabled us to specify the amount of fuel to generate $1 \mathrm{kWh}$ of electrical energy.

Key words: efficiency, engine, city bus, electrical energy

\section{Introduction}

The transportation sector is the second largest energy consumer with its consumption of about $30 \%$ of total global consumption [1]. The IEA report [10] states that $19 \%$ of global energy consumption is for road transportation that, in turn, produces $23 \%$ of global $\mathrm{CO}_{2}$ emissions. Energy consumption by transportation, especially road, has increased much in the past few decades. Crude oil is the primary fuel and hydrocarbons capable of covering the primary energy demand [11].

Vehicles are chiefly driven by compression-ignition internal combustion engines which show high torque over a wide range of speed, which enables efficient daily passenger transportation. The city bus drives about $250 \mathrm{~km}$ per day in a medium-sized city in Poland and its typical drive proceeds in the following stages, in order of their frequency: idling, accelerating and braking, and steady-state driving. At the same time, the diesel engine remains a main source of mechanical energy in transportation. Its developed control system and highly efficient working process of more than $40 \%$ make it widely used. [16]. The generated energy is chiefly used to drive the vehicle, but also multiple engine-driven receivers such as an air conditioner's compressor, a brake system's compressor or alternators for which there are very often installed two or three receivers of a more than $10 \mathrm{~kW}$ total power. These devices should be powered by the adequate on-board generated amount of energy. This means that on-board generated electricity consumed by the city bus is a large share of its total energy consumption. The research results [8] show that the city bus consumes between $15 \mathrm{kWh}$ and $30 \mathrm{kWh}$ of electricity a day. This range of consumption depends on on-board devices, i.e. an air-conditioner, ticket machines, monitors. It should also be remembered that electric power demand in vehicles is constantly increasing [4] for example, due to applying electric power steering [5]. This trend has been clearly visible for the last two decades [17]. Car alternator efficiency reaches $70 \%$, but due to transient operating conditions defined by rotational speed and current load, the average alternator efficiency is much lower than the maximum. It is estimated to range between $50 \%$ and $62 \%[2,3]$. There have been many attempts to improve the efficiency of alter- nators $[7,12]$ however, the solution to reduce mechanical losses due to powering 3 alternators is to use only one but large.

Given that the 12-meter bus consumes 351 of fuel per $100 \mathrm{~km}$ and its average mileage is $250 \mathrm{~km}$ per day, its chemical energy consumption in fuel is $875 \mathrm{kWh}$ per day. About $5 \%$ of that could be spent to generate electric energy. Obviously, this amount also depends on engine load. The drive unit dedicated to buses shows high displacement, which, unfortunately, causes high exhaust gas flow rate and considerable mileage fuel consumption defined in $\mathrm{kg} / 100$ $\mathrm{km}$ or $\mathrm{dm}^{3} / 100 \mathrm{~km}$. Continuously changed loads cause, therefore, the larger than in constant-speed driving increase in emissions of toxic substances like $\mathrm{PM}, \mathrm{NO}_{\mathrm{x}}, \mathrm{CO}$ and $\mathrm{CO}_{2}$. It should also be noted that for every liter of diesel used there is emitted about $2.6 \mathrm{~kg}$ of $\mathrm{CO}_{2}$ [6]. The results [14] show that the passenger transportation sector in the Lower Fraser Valley in British Columbia, Canada consumed $19050 \mathrm{GWh}$ of energy in just one year. This consumption contributed to 5.47 million tons of $\mathrm{CO}_{2}$ emissions. A significant share of this emission, especially by city buses, is due to their electricity demand. The amount of fuel used and $\mathrm{CO}_{2}$ emitted depends, among others, on the total electricity generation efficiency in an electrical way and is the product of the efficiencies of the engine, the transmission belt and the alternator.

Therefore, this research aimed at determining the onboard electricity generation efficiency of a city bus under the defined engine operating conditions and varied alternator electric loads enabled by a chassis dynamometer.

\section{The research object and test stand}

The research object is a bus owned by Miejskie Przedsiębiorstwo Komunikacyjne Lublin S.A. It is the Mercedes Conecto LF with the OM 926 LA inline 6-cylinder diesel engine of a maximum power of $205 \mathrm{~kW}(278 \mathrm{hp})$ and a displacement of $7.23 \mathrm{dm}^{3}$, see Figure 1. The engine satisfies Euro IV emission standard with the use of the BlueTec technology based on injecting a special liquid, AdBlue, into the catalytic converter to burn out exhaust gas. Electricity is generated by two alternators of a total maximum current of 200 A (vehicle's electrical installation, punchers, monitor- 
ing system and displays) and a 140-watt alternator installed in air-conditioned vehicles.

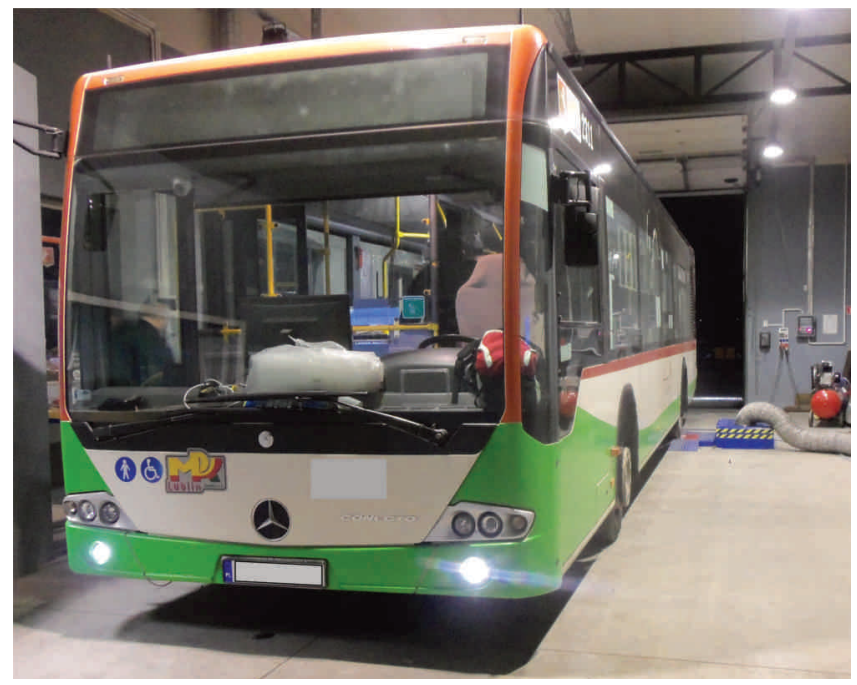

Fig. 1. Research object at the chassis dynamometer

The chassis dynamometer MAHA LPS 3000 LKW enables repetitive measurement conditions and test bench simulations reproducing road conditions, both steady and transient, to investigate the drive unit. This type of research enables also non-weather dependent measurement conditions, and there is no need to deliver the research vehicle to the research road section. Moreover, test bench research allows us to use measuring instruments more efficiently and research conditions are repetitive, which can be hardly possible in typical road conditions. Accordingly, we have managed to perform steady state measurements, which is a basic assumption behind this research [13].

Figure 1 shows a schematic diagram of the test bench: MAHA LPS3000 LPS chassis dynamometer, SEMTECH exhaust gas analyzer, National Instruments data acquisition system.

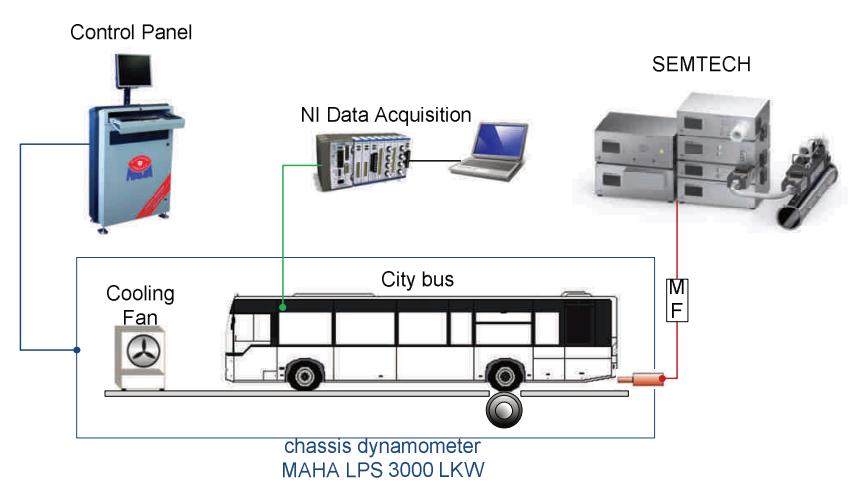

Fig. 2. Test bench

The system for data acquisition, analysis and archiving consisted of:

- real-time controller NI CompactRIO-9024,

- CAN Interface Module NI 9862,

- data acquisition card module NI CompactRIO-9118,

- data acquisition card.
The data from the CAN interface module of the engine control unit were sent in line with the FMS (Fleet Management Systems Interface) standard. Connected to the data acquisition system CompactRIO, the LEM HTR 300-SB current transducer was installed on the cable that connects alternators and a battery.

\section{Research scope and aim}

The steady-state test cycle was a sequence of measurement points of defined speed and torque at which the engine is investigated in line with the World Harmonized Stationary Cycle (WHSC) [15]. Steady-state research is if vehicle's speed is constant, i.e. crankshaft speed is constant, and an accelerator pedal is in a constant position, which corresponds a fixed dose of fuel. A linear WHSC cycle consists of several standard phases of crankshaft speed and load that are calculated into reference values for a specific engine in line with a calibration curve of operating parameters. The engine needs to operate for a defined period of time in each phase of the cycle, and rotational speed and load are changed every $20 \pm 1 \mathrm{~s}$. Actually, certain measurement points were investigated due to the constrained architecture of our test bench, and the research scope was modified due to the measurements at each point with different electrical loads, i.e. $0.4 \mathrm{~kW}, 2.6 \mathrm{~kW}, 2.8 \mathrm{~kW}$. The research results enabled us to define the amount of fuel that was used only to generate electricity.

To define the operating points, rotational speed was calculated according to the formulae $[9,15]$.

Figure 3 shows the measurement points and research results for urban conditions.

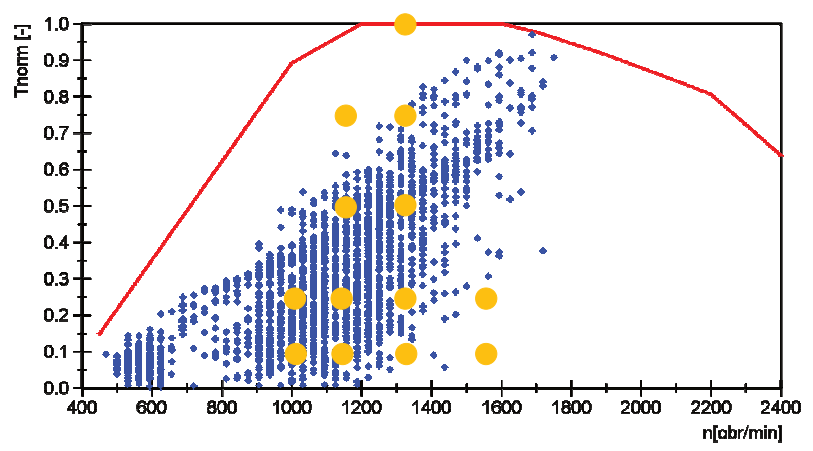

Fig. 3. Normalized torque as a function of crankshaft rotational speed and a series of measurement points

The following parameters were registered:

- power,

- torque,

- engine speed,

- accelerator pedal position (APP),

- fuel consumption per hour,

- carbon dioxide mass flow,

- voltage and electric current of the bus electrical installation.

\section{Research results}

This paper presents the research results for a single measurement point of $n=1,165 \mathrm{rpm}, M_{n}=0.1$, see Fig. 4 .

Our steady-state research allowed us to specify the amount of fuel consumed and carbon dioxide produced due 
to the load generated by the on-board electrical devices. Our research examined engine power, electric power, fuel consumption per hour and $\mathrm{CO}_{2}$ emission. The figure below depicts the results for the measurement point defined by crankshaft rotational speed and a standard torque. Modified by means of an extra receiver, i.e. light bulbs, the electrical load was $0.4 \mathrm{~kW} 1.6 \mathrm{~kW}$ and $2.8 \mathrm{~kW}$. For each of these values, there were measurements for three positions of the accelerator pedal position, which corresponded changes in fuel consumption per hour and power on wheel. Registration time in each measurement point was at least $25 \mathrm{~s}$.
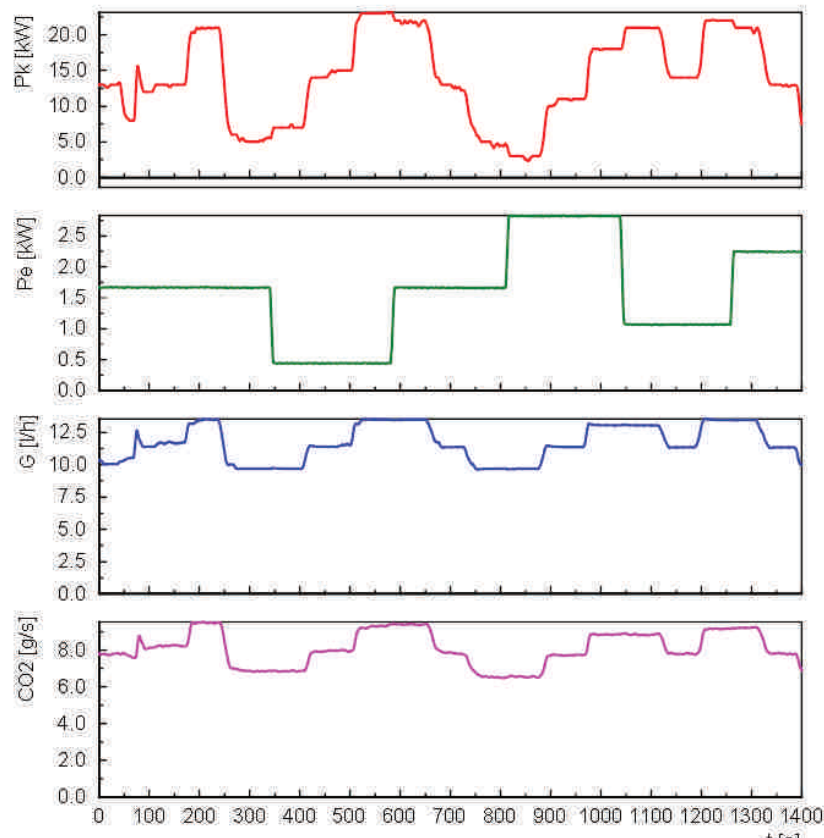

Fig. 4. Research results for the measurement point defined by $\mathrm{n}=1,165$ $\mathrm{rpm}, \mathrm{M}_{\mathrm{n}}=0.1, \mathrm{P}=14 \mathrm{~kW}$

The examination at the defined measurement point was as follows. The research results enabled us to correlate power on wheels and fuel consumption per hour. Accordingly, the wheel power for the same APP but varied electric power generated by the alternators was compared. Then, a horizontal straight line, corresponding to power required at a given measurement point, here $14 \mathrm{~kW}$ (Fig. 5), was marked. The points of intersection between horizontal straight line $\mathrm{y}=14$ and three straight lines to approximate the power at varied electrical loads indicate the amount of fuel to generate electricity. This method enables us to specify the amount of fuel to generate electrical energy. This difference results from the fact that for various electrical loads the same value of power on wheels, or desired speed requires fuel dosing to be modified. The research results in line with the methodology above are depicted in Fig. 5. The formulae to calculate the amount of fuel to generate $1 \mathrm{kWh}$ of electricity can be as follows:

$$
\mathrm{G}_{\mathrm{kWh} 1}=\left(\left(\mathrm{G}_{2}-\mathrm{G}_{1}\right) / \mathrm{P}_{2}-\mathrm{P}_{1}\right)
$$

and

$$
\mathrm{G}_{\mathrm{kWh} 2}=\left(\left(\mathrm{G}_{3}-\mathrm{G}_{2}\right) / \mathrm{P}_{3}-\mathrm{P}_{2}\right)
$$

where: $G_{\mathrm{kWh} 1,2}$ - amount of fuel to generate $1 \mathrm{kWh}$ of electrical energy, $\mathrm{dm}^{3} / \mathrm{kWh} ; \mathrm{G}_{1,2,3}$ - fuel consumption per hour, $\mathrm{dm}^{3} / \mathrm{h} ; \mathrm{P}_{1,2,3}$ - electric power, $\mathrm{kW}$.

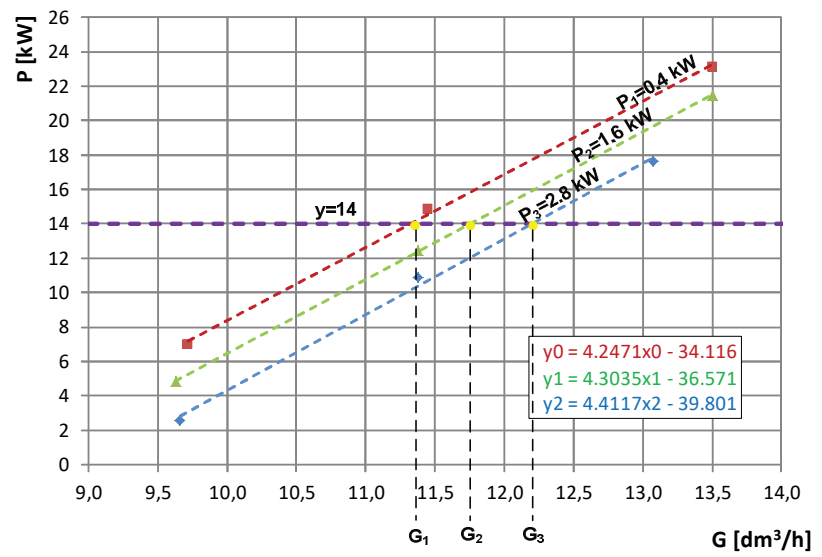

Fig. 5. Power on wheel vs. fuel consumption per hour for three options of electrical load

The following values were calculated: $\mathrm{G}_{\mathrm{kWh} 1}=0.345$ $\mathrm{dm}^{3} / \mathrm{kWh}, \mathrm{G}_{\mathrm{kWh} 2}=0.383$ litres $/ \mathrm{kWh}$. Our further analysis was based on the average value of $\mathrm{GkWh}=0.364$ $\mathrm{dm}^{3} / \mathrm{kWh}$.

Then, these results enabled us to specify the efficiency of electricity generation. It was assumed that a liter of diesel oil contains $E_{p}=9.7 \mathrm{kWh}$ of chemical energy $[8,18]$. Accordingly, it can be calculated that the obtained average value of $\mathrm{G}_{\mathrm{kWh}}=0.364 \mathrm{dm}^{3}$ contains $\mathrm{E}_{\mathrm{kWh}}=3.534 \mathrm{kWh}$ of energy. Hence, the efficiency of electricity generation calculated as $1 \mathrm{kWh}$ energy generated divided by $\mathrm{E}_{\mathrm{kWh}}$ - the supplied chemical energy contained in the fuel reaches $28 \%$.

\section{Summary}

The research discussed in this paper is preliminary and aims at presenting the methodology to specify the efficiency of on-board electricity generation based on the WHSC test. For the measurement point of $\mathrm{n}=1,165 \mathrm{rpm}, \mathrm{P}=14$ $\mathrm{kW}$, efficiency reaches $28 \%$. This efficiency does not cover, however, the efficiency of in-battery energy storage. Our further research shall be done for other measurement points defined by the WHSC test.

\section{Nomenclature}

APP accelerator pedal position

$\mathrm{E}_{\mathrm{kWh}} \quad$ electric energy

$\mathrm{G}_{\mathrm{kWh} 1,2}$ amount of fuel to generate $1 \mathrm{kWh}$ of electrical energy
$\mathrm{G}_{1,2,3}$ fuel consumption per hour

$\mathrm{P}_{1,2,3} \quad$ electric power

$\mathrm{T}_{\text {norm }} \quad$ normalized torque

WHSC world harmonized stationary cycle 


\section{Bibliography}

[1] BADRUDDIN, A., MEKHILEF, S., SILITONGA, A.S., ATABANI, A.E. A review on global fuel economy standards, labels and technologies in the transportation sector. Renewable and Sustainable Energy Reviews Renewable and Sustainable Energy Reviews. 2011, 15, 4586-4610.

[2] BOSCH, R. Automotive handbook, fourth ed. Bentley Publishers, Cambridge, MA 1996.

[3] BRADFIELD, M. Improving alternator efficiency measurably reduces fuel costs. Remy, Inc.

[4] BRADFIELD, M. Improving alternator efficiency measurably reduces fuel costs. Delco Remy, 2008.

[5] Daimler Buses relying on intelligent steering systems. media.daimler.com.

[6] Emission factors for greenhouse gas inventories www.epa.gov.

[7] GONEN, E., GROSSMAN, G. Effect of variable mechanical resistance on electrodynamic alternator efficiency. Energy Conversion and Management. 2014, 88, 894-906.

[8] GRABOWSKI, Ł., PIETRYKOWSKI, K., GECA, M., BARAŃSKI, G. The electric power generation efficiency in city bus. SAE Technical Paper. 2014, 2014-01-2898.

[9] HEINZ, S. Development of a world-wide harmonised heavy-duty engine emissions test cycle. Executive Summary Report. ECE-GRPE WHDC Working Group, 2001.

Łukasz Grabowski, DSc., DEng. - Faculty of Mechanical Engineering at the Lublin University of Technology.

e-mail:L.Grabowski@pollub.pl

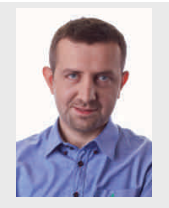

Grzegorz Barański, DSc., DEng. - Faculty of Mechanical Engineering at the Lublin University of Technology.

e-mail: G.Baranski@pollub.pl
[10] IEA, Transport, Energy and $\mathrm{CO}_{2}$. Paris. 2009.

[11] JANUSZ, P. Ropa naftowa - kierunki dostaw i struktura zużycia w Polsce w latach 1999-2011, NAFTA-GAZ. 2013, 1.

[12] MA, Q., BRAHMA, A., RIZZONI, G. Idle speed control for automotive engines with an integrated starter alternator. 15th Triennial World Congress. Barcelona, Spain.

[13] Materiały informacyjne firmy MAHA. www.maha.pl.

[14] POUDENXA, P., MERIDA, W. Energy demand and greenhouse gas emissions from urban passenger transportation versus availability of renewable energy: The example of the Canadian Lower Fraser Valley. Energy. 2007, 32, 1-9.

[15] Regulamin nr 49 Europejskiej Komisji Gospodarczej Organizacji Narodów Zjednoczonych (EKGONZ).

[16] RIBEIRO, N.M., PINTO, A.C., QUINTELLA, C.M. et al. The role of additives for diesel and diesel blended (ethanol or biodiesel) fuels: a review. Energy Fuels. 2007, 21, 24332445.

[17] ROZDMAN, K., REDUAN, M., MOHD, Z., ABDUL, H.A. Experimental study on the effect of alternator speed to the car charging system. MATEC Web of Conferences 9001076.

[18] THOMAS, V.M., MEIER, A.K., GUNDA, S.G., WENZE, I.T.P. Cars are buildings: building-like energy use in automobiles. Transportation Research Part D. 2011, 16, 341345 .

Prof. Mirosław Wendeker, DSc., DEng. - Faculty of Mechanical Engineering at the Lublin University of Technology.

e-mail: M.Wendeker@pollub.pl

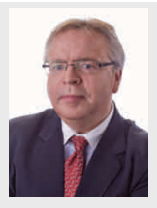

Mariusz Duk, DSc., DEng. - Faculty of Electrical

Engineering and Computer Science at the Lublin

University of Technology.

e-mail:M.Duk@pollub.pl 